\title{
KEPRIBADIAN GURU PENDIDIKAN AGAMA ISLAM MENURUT BUYA HAMKA
}

\author{
Laela Hamidah Harahap ${ }^{1}$, Sawaluddin ${ }^{2}$ Nuraini $^{3}$ \\ ${ }^{1}$ Fakultas Pendidikan Agama Islam \\ Progaram Pasca Sarjana (PPs) \\ Universitas Islam Negeri Sultan Syarif Kasim Riau \\ hamidahlaila59@gmail.com \\ ${ }^{2}$ Sekolah Tinggi Agama Islam Negeri (STAIN) Mandailing Natal \\ Regarsawaluddin@gmail.com \\ ${ }^{3}$ Sekolah Tinggi Agama Islam Negeri (STAIN) Mandailing Natal \\ Nuraini01979@gmail.com
}

Website: https://jurnal.uin-antasari.ac.id/index.php/jtjik/index

Received: 8 Mei 2019; Accepted: 23 Desember 2019; Published: 26 Desember 2019

\begin{abstract}
The teacher is a position or profession that requires special skills as a teacher. This work cannot be done by people who do not have the expertise to carry out activities or work as a teacher.. Good character does not just appear, it is a lifelong learning process. To grow good character, a teacher can learn about the lives of characters who are considered to have good character or personality. The research conducted was included in the type of qualitative descriptive research with library research. The analysis in this study uses the method of content analysis. The results of the study are that the teacher according to Hamka functions as an institution that seeks to develop all the potential that exists in students to the fullest, in accordance with the rhythms of their development, both physicaly and mental spiritual have a good personality because students will imitate the behavior of his teacher. Teacher's Personality in Islamic Education According to Buya Hamka's Thought, the teacher must understand the concept of the educator as an exemplary subject, the tasks of the educator, and have character (traits), as befits an educator. Hamka expressed his opinion about how should the characteristics of Islamic religious education teachers, namely: 1) Having extensive knowledge, 2) Good communication, 3) Good example for students and those around them, 4) Ikhlash, 5) Having good methods for teaching, 6) Humility, 7) Responsibility, 8) Confidence, 9) Gentleness, 10) Patience, 11) Passion, 12) Apply and say honestly.
\end{abstract}

Keyword: Teacher Personality, Buya Hamka

\begin{abstract}
ABSTRAK
Setiap guru mempunyai kepribadian dan latar belakang dan pengalaman mengajar yang berbeda. Kepribadian sebenarnya adalah suatu yang abstrak, hanya dapat dilihat lewat penampilan, tindakan, ucapan, cara berpakaian, dan cara menghadapi setiap persoalan. Penelitian yang dilakukan ini adalah termasuk dalam jenis penelitian deskriptif kualitatif dengan library research. Analisis pada penelitian ini menggunakan cara content analysis. Hasil penelitian adalah Guru menurut Hamka berfungsi sebagai lembaga yang berupaya mengembangkan seluruh potensi yang ada dalam diri peserta didik secara maksimal, sesuai dengan irama perkembangannya, baik jasmaniah maupun mental spiritual memiliki kepribadian yang baik karena peserta didik akan mencontoh ataupun meniru tingkah laku gurunya. Kepribadian Guru Dalam Pendidikan Agama Islam Menurut Pemikiran Buya Hamka ialah guru harus memahami konsep pendidik sebagai subjek yang dapat diteladani, tugas-tugas pendidik, dan memiliki karakter (sifat-sifat), sebagaimana layaknya seorang pendidik. Hamka mengemukakan pendapatnya mengenai bagaimana harusnya sifat-sifat guru pendidikan agama Islam, yaitu : 1) Memiliki pengetahuan yang luas, 2) Komunikasi yang baik, 3) Tauladan yang baik bagi peserta didik
\end{abstract}


dan yang disekitarnya, 4) Ikhlash, 5) Memiliki metode mengajar yang baik, 6) Rendah hati, 7) Tanggung jawab, 8) Percaya diri, 9) Lemah lembut, 10) Sabar, 11) Semangat, 12) Berlaku dan berkata jujur.

Kunci : Kepribadian Guru, Buya Hamka

PENDAHULUAN

Pendidikan Islam adalah segala usaha untuk memelihara dan mengembangkan fitrah manusia serta sumber daya insan yang berada pada subjek didik menuju terbentuknya manusia seutuhnya (insan kamil) sesuai dengan norma Islam atau dengan istilah lain yaitu terbentuknya kepribadian muslim (Achmadi, 1992: 14). Sementara itu Hamka menjelaskan tentang pendidikan Islam didasarkan pada empat aspek yaitu; (الفطرة) peserta didik; jiwa (القلب), Jasad (العقل), dan akal (العزم) dengan empat aspek tersebut jelas bahwa Hamka lebih menekankan pemikiran pendidikannya pada aspek pendidikan jiwa atau akhlakulalkarimah (budi pekerti) (Samsul Nizar, 2008: 120). Sehingga Hamka membedakan makna pendidikan dan pengajaran. Menurutnya pendidikan Islam merupakan serangkaian upaya yang dilakukan pendidik untuk membantu membentuk watak, budi, akhlak, dan kepribadian peserta didik, sehingga ia tahu membedakan mana yang baik dan mana yang buruk. Untuk membentuk watak, budi, akhlak, dan kepribadian peserta didik, maka peran guru sangat di perlukan.

Guru merupakan pendidik formal di sekolah yang bertugas membelajarkan peserta didik-peserta didiknya sehingga memperoleh berbagai pengetahuan, keterampilan, nilai dan sikap yang semakin sempurna kedewasaan atau pribadinya. Karena itulah, guru terkait dengan berbagai syarat, yang diantaranya guru disyaratkan untuk memiliki sepuluh kemampuan dasar yaitu: menguasai bahan, mengelola program belajar mengajar, mengelola kelas, menguasai media atau sumber belajar, menguasai landasan kependidikan, mengelola interaksi belajar mengajar, menilai prestasi peserta didik, mengenal fungsi dan program bimbingan penyuluhan, mengenal dan menyelenggarakan administrasi sekolah, serta memahami prinsip-prinsip dan menafsirkan hasil penelitian untuk keperluan pendidikan dan pengajaran (Zainal Aqib, 2002 : 103-110).

Kepribadian mempunyai pengaruh langsung dan kumulatif terhadap hidup dan kebiasaan-kebiasaan belajar siswa. sejumlah percobaan dan hasil-hasil observasi menguatkan kenyataan bahwa banyak sekali yang dipelajari oleh siswa dari gurunya. Pengalaman menunjukkan bahwa masalahmasalah seperti motivasi, disiplin, tingkah laku sosial, prestasi, dan hasrat belajar yang terus-menerus pada diri siswa yang bersumber dari kepribadian guru ( Suyanto dan Asep Jihad, 2013:16).

Menjadi guru menuntut suatu personalitas/kepribadian yang terpuji, tangguh dan antisipatif, dengan keterpujian maka dorongan untuk menjadikan masa depan yang lebih beradab menjadi kuat; dengan ketangguhan, maka masa depan bangsa yang kuat dalam berjuang menjadi lebih nyata, dan dengan antisipatif maka arah masa depan menjadi makin jelas tertata dalam menjalankan peran dan tugas sebagai guru (Uhar Suharsaputra, 2013:35).

Bukan suatu kebetulan apabila sikap dan perilaku peserta didik dipengaruhi oleh bagaimana kepribadian, sikap dan perilaku guru dalam menyikapi dan memperlakukan peserta didik dalam lingkungan pendidikan di sekolah, sudah tentu faktor-faktor pribadi 
yang dibawa peserta didik (Uhar Suharsaputra, 2013:66).

Pribadi guru memiliki andil yang sangat besar terhadap keberhasilan pendidikan, khususnya dalam kegiatan pembelajaran. Pribadi guru juga sangat berperan dalam pembentukan pribadi peserta didik. Ini dapat dimaklumi karena manusia merupakan makhluk yang suka mencontoh, termasuk mencontoh pribadi gurunya dalam membentuk kepribadiannya. Semua itu menunjukkan bahwa kompetensi personal atau kepribadian guru sangat dibutuhkan oleh peserta didik dalam proses pembentukan pribadinya. Sebagai seorang pendidik/guru yang mengemban tugas membentuk kepribadian sehingga mampu melahirkan anak bangsa yang berkepribadian unggul.

Kepribadian yang akan menentukan apakah seorang guru akan menjadi pendidik dan pembina yang baik bagi para siswanya, ataukah akan menjadi perusak atau penghancur bagi hari kedepan peserta didiknya. Faktor kepribadian akan semakin menetukan peranannya pada peserta didik yang masih kecil dan sedang mengalami keguncangan jiwa (Ngainun Naim, 2009:36).

\section{HASIL PENELITIAN}

Ada beberapa istilah bahasa Arab yang mengacu kepada makna pendidikan dalam Islam diantaranya adalah tarbiyah, ta'dib, ta'lim dan tahzib. Kata tarbiyah yang berasal dari kata برyang berarti mengembangkan, menumbuhkan; bertambah. Dalam hal ini bisa diterjemahkan dengan mendidik sesuai dengan potensi yang ada atau menumbuhkan potensi yang ada yang sesuai dengan fitrah manusia Pendidikan Islam adalah segala usaha untuk memelihara dan mengembangkan fitrah manusia serta sumber daya insan yang berada pada subjek didik menuju terbentuknya manusia seutuhnya (insan kamil) sesuai dengan norma Islam atau dengan istilah lain yaitu terbentuknya kepribadian muslim (Achmadi, 1992: 14). Sementara itu Hamka tentang pendidikan Islam didasarkan pada empat aspek yaitu; (الفطرة) peserta didik; jiwa (القلب), Jasad ( (الجسم), dan akal (العقل) dengan empat aspek tersebut jelas bahwa Hamka lebih menekankan pemikiran pendidikannya pada aspek pendidikan jiwa atau akhlakulalkarimah (budi pekerti) (Samsul Nizar, 2008: 120). Berdasarkan penjelasan tersebut menurut hamka pendidikan sebagai sarana yang dapat menunjang dan menimbulkan serta menjadi dasar bagi kemajuan dan kejayaan hidup manusia dalam berbagai ilmu pengetahuan. Pendidikan tersebut tergabung dalam dua prinsip yang saling mendukung, yaitu prinsip keberanian dan kemerdekaan berpikir (Hamka, 1980: 208). Selain dari itu Hamkajuga menjelasakan membedakan makna pendidikan dan pengajaran. Menurutnya pendidikan Islam merupakan serangkaian upaya yang dilakukan pendidik untuk membantu membentuk watak, budi, akhlak, dan kepribadian peserta didik, sehingga ia tahu membedakan mana yang baik dan mana yang buruk. Dalam membentuk watak, budi, akhlak, dan kepribadian peserta didik, maka peran guru sangat di perlukan. Oleh sebab itu utuk lebih jelasnya bagaimana konsep kepribadian guru menurut Hamka akan di uraikan dengan jelas dibawah ini:

\section{Hakikat Guru Pendidikan Agama Islam Menurut Buya Hamka \\ Guru menurut Hamka berfungsi sebagai lembaga yang berupaya mengembangkan seluruh potensi yang ada dalam diri peserta didik secara maksimal, sesuai dengan irama perkembangannya, baik jasmaniah maupun mental spiritual. (Hamka, 1983:148-149). Sebagaimana}


pandangan Hamka terkait pendidik sangatlah besar upayanya dalam mewujudkan peserta didik yang mampu mengoptimalkan akalnya, meraih citacitanya, dan mengarahkan cita-cita tersebut pada nilai-nilai yang dinamis dan religius. Seorang pendidik dikatakan berhasil apabila peserta didik mencapai kemajuannya. Guru Agama Islam adalah figur sentral yang harus dapat diteladani akhlaknya, disamping keilmuan dan akademiknya. Selain itu, guru hendaknya mempunyai tanggungjawab moral dan keagamaan, untuk membentuk peserta didiknya menjadi orang yang berilmu dan berakhlaq. Dan guru hendaknya tidak lupa melupakan empat hal yang perlu diperhatikan yaitu : mendidik, mengajar, melatih dan meneliti (Syamsul Ma'arif, 2012:26).

Guru harus bisa menanamkan keberanian pada diri peserta didik untuk berani berargumentasi dan mengeluarkan pendapat, hal ini bisa diupayakan dengan jalan menguatkan pelajaran olahraga, menceritakan riwayat orang-orang yang berani, membiasakan berterus terang dalam bercakap-cakap, tidak percaya pada khurafat, dan memperkaya akal dan ilmu yang memberi faedah (Hamka,1984: 208209).

Menurut Buya Hamka berpendapat bahwa pendidik adalah sosok yang bertanggung jawab dalam mempersiapkan dan mengantarkan peserta didik untuk memiliki ilmu pengetahuan yang luas, berakhlak mulia, dan bermanfaat bagi kehidupan masyarakat secara luas (Hamka,1983:2-3). Guru hendaknya memiliki kepribadian yang baik karena peserta didik akan mencontoh ataupun meniru tingkah laku gurunya. Peserta didik maupun masyarakat akan beranggapan bahwasanya guru adalah manusia sempurna yang patut dicontoh. Kepribadian menurut Buya Hamka sebagai berikut : a. Kumpulan sifat dan kelebihan diri yang menunjukkan kelebihan seseorang daripada oranglain sehingga ada manusia besar dan manusia kecil. Ada manusia yang sangat berarti hidupnya dan ada yang tidak berarti sama sekali. Kedatangannya tidak menggenapkan dan kepergiannya tidak mengganjilkan.

b. Kumpulan sifat akal budi, kemauan, citacita dan bentuk tubuh. Menyebabkan harga kemanusian seseorang berbeda dari yang lain (Hamka,2014:4).

Dengan budi yang tinggi, kesopanan, ilmu pengetahuan yang luas, kesanggupan menahan hati pada perkara yang belum disepakati, dengan kecerdasan, kecepatan menarik kesimpulan, kebagusan susunan kata, kepandaian menjaga perasaan orang, dan kesanggupan menenggang. Kumpulan sifat dan kelebihan itu menimbulkan daya tarik. Hal itu dapat dipelajari dengan pergaulan yang luas dan ada juga karena diwarisi. Pendidikan ibu, bapak, sekolah, teman sejawat, dan lingkungan masyarakat, semuanya itu adalah guru yang membentuk daya penarik. Kuat atau lemahnya (Hamka, 2014:11).

\section{Kepribadian Guru Dalam Pendidikan Agama Islam Menurut Pemikiran Buya Hamka}

Setiap guru mempunyai pribadi masing-masing sesuai dengan ciri-ciri yang miliki. Kepribadian sebenarnya adalah suatu yang abstrak, hanya dapat dilihat lewat penampilan, tindakan, ucapan, cara berpakaian, dan cara menghadapi setiap persoalan (Syaiful Bahri Djamarah,2000:3940). Hamka memberikan gambaran tentang sosok manusia yang pandai tapi tidak memiliki kepribadian yang unggul :

"Banyak guru, dokter, hakim, insinyur, dan orang yang bukunya satu gudang dan diplomanya segulung besar, tiba dalam masyarakat menjadi "mati", sebab dia bukan orang masyarakat. 
Hidupnya hanya mementingkan dirinya, diplomanya hanya untuk mencari harta, hatinya sudah seperti batu, tidak mempunyai cita-cita lain kecuali kesenangan dirinya. Pribadinya tidak kuat. Dia bergerak bukan karena dorongan jiwa dan akal. Kepandaiannya yang banyak itu kerap kali menimbulkan takutnya. Bukan menimbulkan keberaniannya memasuki lapangan hidup" (Hamka,2014:3).

Guru harus memahami konsep pendidik sebagai subjek yang dapat diteladani, tugastugas pendidik, dan memiliki karakter (sifatsifat), sebagaimana layaknya seorang pendidik. Hamka mengemukakan pendapatnya mengenai bagaimana harusnya sifat-sifat guru pendidikan agama Islam, yaitu : 1) Memiliki pengetahuan yang luas, 2) Komunikasi yang baik, 3) Tauladan yang baik bagi peserta didik dan yang disekitarnya, 4) Ikhlash, 5) Memiliki metode mengajar yang baik, 6) Rendah hati, 7) Tanggung jawab, 8) Percaya diri, 9) Lemah lembut, 10) Sabar, 11) Berlaku dan berkata jujur 12) Semangat.

a. Memiliki pengetahuan yang luas

Menjadi guru hendaknya mempunyai ilmu pengetahuan yang luas, memperoleh ilmu tidak hanya dari pendidikan formal, akan tetapi guru harus menambah ilmu pengetahuan dengan berbagai pengalaman dan buku-buku agar menambah wawasan dan memperkuat ilmunya pengetahuannya. Hamka menuliskan pendapatnya sebagai berikut :

"Ilmu pengetahuan yang pada dasarnya bersumber dari percobaan-percobaan dan analisis yang dilakukan secara berulangkali melahirkan kesimpulan fakta (kebenaran) ilmiah yang bersifat universal dan semantara. Ilmu pengetahuan yang yang murni akan senantiasa beriringan dangan agama, begitu pula sebaliknya agama yang murni tidak akan terjadi pertentangan terhadapnya. Apabila terjadi pertentangan diantara ilmu pengetahuan dan agama hal itu membuktikan bahwa ilmu pengatuan atau agama itu tidak murni" (Hamka, 1939:108).

Ilmu pengetahuan menjadi kekuatan besar bagi suatu bangsa. Mulai dari sejak dulu atau sampai sekarang ataupun nanti. Guru harus selalu menambah pengetahuannya. Mengajar tidak dapat dipisahkan dari belajar. Guru yang pekerjaannya memberi pengetahuanpengetahuan dan kecakapan-kecakapan kepada muridnya tidak mungkin akan berhasil baik jika guru itu sendiri tidak selalu berusaha menambah pengetahuannya. Jadi sambil mengajar sebenarnya guru itu belajar. Selain mempunyai pengetahuan yang dalam tentang mata pelajaran yang sudah menjadi tugasnya akan lebih baik lagi jika guru itu mengetahui pula tentang segala tugas yang penting-penting, yang ada hubungannya dengan tugasnya di dalam masyarakat. Guru merupakan tempat bertanya tentang segala sesuatu bagi masyarakat.

b. Komunikasi yang baik

Tugas dan kewajiban guru tidak hanya terbatas pada sekolah saja tetapi juga dalam masyarakat. Sekolah hendaknya menjadi cermin bagi masyarakat sekitarnya, Sekolah akan asing bagi rakyat jika guru-gurunya menjauhkan diri dari masyarakat, tidak suka bergaul atau mengunjungi orang tua peserta didiknya. Masyarakat disekitarnya akan lebih menyukai apabila guru dapat berkomunikasi dengan baik. Buya Hamka menggambarkan cara berkomunikasi yang baik terhadap sekitar yaitu :

"Lidah mewakili kebatinan kita. Ia menunjukkan kecerdasan pikiran, kedalaman pembelajaran dan pemahaman, serta banyak pengalaman. Bagaimana pun gagah atau manisnya seseorang, biarpun 
banyaknya ilmu yang dimiliki, jika lidahnya kelu, apalah jadinya! Padahal, lidah adalah magnet untuk menarik orang lain supaya dapat berhubungan dengan kita. Bukankah hidup akan sunyi jika hanya sendiri"? (Hamka,2014:53).

Berdasarkan kutipan tersebut Buya Hamka menjelaskan bahwa lidah adalah salah satu cara komunikasi yang baik untuk menarik orang lain agar dapat berhubungan dengannya.

c. Tauladan yang baik bagi peserta didik dan yang disekitarnya

Guru harus menjadi contoh yang baik dalam hal kepribadian, agar dapat menjadikan peserta didiknya berakhalakul karimah. Hamka berpendapat bahwa:

"Maka hendaklah seorang menjadi contoh yang baik bagi peserta didiknya, perangai patut ditiru, menjadi ayah dari peserta didiknya, menjadi sahabat tempat menumpahkan perasaan hati dan mengadu di waktu pikiran tertumpuk. Bergaul dengan peserta didiknya itu dengan sikap lemah lembut, tetapi tidak tersudu, keras tetapi penyayang, lemah lembut, tetap merdeka $\mathrm{d}$ an bebas, terus terang dan tidak sembunyi-sembunyi. Kadang-kadang sikapnya keras tetapi di dalam kerasnya itu si peserta didiknya merasa sendiri, bahwa pada waktu itu, memang sudah seadilnya jika gurunya keras kepadanya. Kekerasan sekali-sekali, samalah artinya dengan garam penambah enaknya sambal" (Hamka, 1983:71).

Guru hendaknya memiliki perilaku yang baik, mendahulukan keteladanan dirinya, karena anak didik memperhatikan segala perilaku pendidiknya, telinga mereka pun setia mendengarkan. Apa yang menurut seorang pendidik baik, maka dimata mereka juga dianggap baik.

Seorang guru merupakan sosok yang dijadikan teladan bukan saja bagi anak didik, tetapi juga masyarakat. Guru juga merupakan salah satu faktor yang paling menentukan berhasilnya suatu proses belajar mengajar, karena itu guru tidak saja menduduki fungsi sebagai orang dewasa yang bertugas memindahkan ilmu pengetahuan (transfer of knowledge) yang dikuasainya kepada anak didik dalam aspek kognitif tetapi lebih jauh dari itu, setiap pendidik harus menanamkan nilainilai kepribadian atau sikap (afektif) yang positif serta kemampuan untuk menjadikan peserta didik lebih dewasa, madiri, dan mengembangkan kemampuan dan keterampilan (psikimotorik) peserta didik.

d. Ikhlash

Seorang guru hendaknya tidak menjadikan profesinya untuk mencari kesenangan duniawi, dengan kata lain seorang guru harus ikhlash dalam profesinya. Semata-mata yang diharapkan hanyalah ridho dari Allah SWT. Tujuan awal dari seorang guru akan mempengaruhi kinerja dalam proses pendidikan selanjutnya. Bila seorang guru memberikan ilmu semata-mata hanya untuk mengharapkan agar mendapatkan uang, bisa dikatakan dengan penjual ilmu, mendidik hanya untuk sekedar mengugurkan kewajibannya saja. Dengan ikhlash maka akan menimbulkan minat dan tidak merasa bosan dan lelah dalam mengajar. Segalanya akan menjadi mudah, halangan dan rintangan akan menjadi mudah (Hamka,2017:182).

"Seorang yang patut disebut mulia atau budiman, ialah bersikap terus terang, ikhlas jujur pada perkataan dan perbuatannya. Tidak mengambil muka, tidak pula hanya suka dipuji dan tidak tabah ketika dicela. Dia mengerjakan perbuatan baik bukan karena yang lain, tapi semata-mata karena kebaikan itu adalah kebaikan. Tidak pula melupakan 
jasa orang lain terhadap dirinya, pada menenggang rasa (Hamka,1983:203).

Ikhlash dalam menjalankan pekerjaan sebagai guru adalah landasan dari keberhasilan. Guru yang ikhlas tidak akan tersesat dan terperosok oleh bujuk rayu Iblis ataupun setan. Akan tetapi guru yang tidak ikhlas tak kan dapat membuahkan kebaikan melainkan hanya akan merugikan dan menyesatkan diri sendiri. Karena suatu saat kedoknya akan terbongkar gara-gara pekerjaannya tidak dilandasi dengan keikhlasan, yang pada akhirnya kawan seperjuangan akan menjauhinya. Lain halnya dengan guru yang ikhlas, ia akan mendapatkan simpati dari warga sekolah dan banyak kawan dalam pergaulan.

e. Memiliki metode mengajar yang baik

Dalam pembelajaran, tidak ada satu metode pun yang dianggap paling baik diantara metode-metode yang lain. Tiap metode mempunyai karakteristik tertentu dengan segala kelebihan dan kelemahan masing masing. Suatu metode mungkin baik untuk suatu tujuan tertentu, pokok bahasan maupun situasi dan kondisi tertentu, tetapi mungkin tidak tepat untuk situasi yang lain. Demikian pula suatu metode yang dianggap baik untuk suatu pokok bahasan yang disampaikan oleh guru tertentu, kadang-kadang belum tentu berhasil dibawakan oleh guru lain. Adakalanya seorang guru perlu menggunakan beberapa metode dalam menyampaikan suatu pokok bahasan tertentu. Dengan variasi beberapa metode, penyajian pembelajaran menjadi lebih hidup. Hamka berpendapat bahwa :

"Pada suatu hari datanglah muridmurid kepada Engku M. Syafei (Alm) meminta supaya hari itu diajarkan pelajaran Ilmu Bumi Ekonomi. Ketika itu mereka sedang berada di halaman sekolah, bukan di dalam kelas. Waktu itu sajalah
Engku M. Syafei memperlakukan permintaan itu sambil berdiri. Diberinya keterangan tentang kekayaan dan kesuburan tanah air, buah-buahan yang bisa tumbuh dan hasil yang dapat dibawanya kepada putera bumi itu sendiri, kalau mereka bersungguh-sungguh. Disuruhnya murid-muridnya itu menentang puncak Gunung Singgalang bahwa di sana ada kekayaan yang tidak tepermanai. Lalu disuruhnya pula mendengarkan bunyi aliran air di Batang Anai yang hebat dahsyat, lalu dinyatakannya pula faedah yang dapat diambil darinya. Sehingga termenunglah murid-murid itu dan lekat di hati mereka keterangan gurunya. Pelajaran seperti itu jauh lebih besar bekasnya kepada jiwa mereka, dari jika disuruh duduk berbaris menghadapi bangku" (Hamka, 1983:70).

Dari kutipan tersebut dapat kita lihat bahwasanya dalam pendidikan metode mengajar itu termasuk hal yang penting. Belajar tidak harus di dalam kelas saja akan tetapi lingkungan sekitar bisa dijadikan tempat belajar. Dengan begitu memiliki metode dan strategi tu penting untuk menghilangkan kejenuhan peserta didik belajar.

f. Rendah hati

Seorang pendidik harus profesional dan juga rendah hati agar bisa menjadi teladan yang baik. Guru profesional harus memiliki sifat dan sikap rendah hati, karena guru bukanlah satusatunya faktor yang menentukan perkembangan anak. Guru yang bersikap rendah hati (tawadhu'), adalah guru yang tidak sombong dan tidak membanggabanggakan dirinya, serta mengakui dan menghargai eksistensi orang lain, termasuk terhadap peserta didiknya.

Sikap guru yang demikian sangat berpengaruh terhadap peserta didik yang ingin mengaktualisasikan diri untuk 
menemukan jati dirinya. Sebab segala pengaruh, terutama dari guru yang menjadi tokoh acuannya, bisa diterima dan diolahnya secara pribadi sesuai dengan individualitasnya masing-masing, yang kemudian menjadi bagian dari dirinya sendiri. Guru harus memiliki sikap rendah hati, seorang pendidik hendaknya bersifat penyantun, pemurah hati terhadap peserta didiknya dan mampu mengendalikan dirinya dari bersikap marah, bersikap lapang dada dan banyak bersabar.

g. Tanggung Jawab

"Keberanian bertanggung jawab akan memunculkan orang yang memuja dan menghargai. Disamping orang yang mencela dan ingin kau jatuh. Kedunya kelak yang mendesak supaya engkau lebih hati-hati dan memperbagus pekerjaan, sehingga seseorang akan bernilai lebih tinggi dari beribu manusia" (Hamka,2014:130).

Berdasarkan kutipan tersebut Buya Hamka menyampaikan bahwa apabila seorang guru mengajar dengan penuh tanggung jawab akan peserta didik akan menghargai dan juga mencela pekerjaannya tersebut. Buya Hamka menjelaskan bahwa kedua hal tersebut seharusnya menjadikan seorang guru untuk mengajar dan mendidik secara lebih hati-hati dan memperbaiki segalanya. Sehingga seorang guru dengan penuh tanggung jawab dan disertai dengan ketelitian serta selalu memperbaiki kepribadiannya akan bernilai lebih tinggi dibandingkan dengan orang lain yang tidak melakukan hal tersebut. Sikap tanggung jawab adalah salah satu faktor yang dapat menambah kepribadian pada seseorang. Hal ini dikarenakan sikap tanggung jawab mampu membuat seorang menjadi pribadi yang lebih kuat kedudukannya di mata masyarakat. Begitu pula sebaliknya seorang guru yang tak memiliki tanggung jawab akan lemah kedudukannya di mata masyarakat. Seperti yang disampaikan Buya Hamka:

"Berani bertanggung jawab membuat orang yang kuat menjadi lebih kuat. Ataupun sebaliknya, suatu pekerjaan yang dipikul dengan tidak penuh tanggung jawab akan membuat yang lemah menjadi lebih lemah" (Hamka,2014:132).

h. Sabar

Kesabaran merupakan syarat yang sangat diperlukan apalagi pekerjaan guru sebagai pendidik. Sifat sabar perlu dimiliki guru baik dalam melakukan tugas mendidik maupun dalam menanti jerih payahnya. Sabar merupakan kesempurnaan dari tanggung jawab. Hamka menjelaskan tentang sabar:

"Bukan hanya halangan dari apa yang benci dan sayang yang akan menghambat. Bahkan, banyak keadaan lain yang harus dihadapi, dilalui atau diatasi. Pengalaman hidup menunjukkan bahwa suatu keadaan yang sulit tidaklah terus dalam kesulitannya. Namun, kita percaya kesulitan itu tidak terus-menerus melainkan akan terlepas dan akan menjadi salah satu mata rantai kenangan hidup" (Hamka,2014:154).

Guru yang mendidik peserta didiknya membutuhkan kesabaran yang tinggi. Guru penyabar menyadari bahwa tugasnya adalah memperbaiki akhlak peserta didiknya. Oleh karena itu, ia tidak akan berputus asa dalam menghadapi sikap dan perilaku mereka yang aneh-aneh dan macam-macam. Apa pun yang terjadi pada mereka, ia terus berusaha memperbaiki dengan penuh rasa tanggung jawab dan tak kenal menyerah.

i. Percaya diri

Tugas guru selain mengajar juga berkewajiban mendorong semangat peserta didik. Melalui sentuhan guru disekolah diharapkan mampu menghasilkan peserta 
didik yang memiliki kompetensi tinggi, dan siap menghadapi tantangan hidup dengan penuh keyakinan dan percaya diri yang tinggi. Guru harus mampu melihat dan memperhatikan kondisi pribadi siswa. Siswa yang cerdasakan cepat mengembangkan keyakinannya akan kemampuan pribadinya. Sedangkan siswa yang kurang cerdas akan sulit mendapatkan bahwa penilaian mereka tentang kemampuannya kurang baik. Keyakinan akan kemampuan diri sangat menentukan dalam mencapai hasil belajar yang baik. Dengan rasa percaya diri yang dimiliki guru maka terlihat dalam tingkah laku positif dan tingkah laku negatif siswa. Percaya kepada diri sendiri adalah hal terakhir yang dijelaskan oleh Buya Hamka dalam bukunya Pribadi Hebat tentang sifat-sifat yang mampu menimbulkan daya tarik pada diri dan orang lain terutama peserta didik.

"Pribadi yang berguna adalah pribadi yang percaya kepada kekuatan diri sendiri. Kekuatan, akal, perasaan, dan kemauan sudah tersedia dalam jiwa sejak dalam kandungan. Semua itu akan muncul dengan pendidikan, pergaulan, dan lingkungan" (Hamka,2014:58).

Pendidikan yang baik akan memunculkan jiwa yang baik pula, dan juga akan melahirkan peserta didik yang memiliki kepribadian yang baik juga. Menjadi percaya kepada diri sendiri termasuk orang yang bebas atau merdeka sejati dalam artinya seseorang itu mampu melakukan hal yang baik tanpa perlu merasa ragu dan cemas. Percaya diri adalah kunci seseorang meraih kesusksesan dan merdeka dari penghambaan terhadap makhluk. Walau manusia sejatinya adalah makhluk sosial dan membutuhkan orang lain dalam menjalani hidup, bukan berarti seseorang harus terus bergantung pada kekuatan orang lain.

Menjadi guru yang percaya diri akan menyanggupi terhadap pekerjaan yang dikerjakan, bertanggung jawab akan hal yang ada dihadapannya termasuk memberi pendidikan yang layak bagi peserta didiknya. Apabila guru percaya diri niscaya peserta didiknya pun akan menjadi perjaya diri karena percaya diri adalah tiang kemerdekaan pribadi dan bangsa. Akan memunculkan kekuatan, tabiat, akhlak dan budi. Karena memang demikianlah tujuan guru untuk menjadikan peserta didiknya memiliki kekuatan dalam belajar, tabiat, akhlak dan budi yang baik.

j. Lemah lembut

Bersifat lemah lembut bukan berarti bersikap lunak, tidak cepat berpindah dari suatu pendirian dan jujur dalam perkara yang belum diketahui. Lemah lembut haruslah tegas, agar segala kesulitan dapat terselesaikan dengan mudah karena kelapangan dada menghadapinya dan tidak gegabah. Dengan lemah lembut akan mempunyai daya tarik (Hamka,2014:12).

Apabila peserta didik merasa diperlakukan dengan lemah lembut oleh gurunya, ia akan merasa percaya diri dan tentram (ada rasa aman) berdampingan bersamanya. Perasaan inilah yang akan lebih banyak menunjang tercapainya ilmu k. Berlaku dan berkata jujur Jujur merupakan perilaku yang didasarkan pada upaya menjadikan dirinya sebagai orang yang selalu dapat dipercaya dalam perkataan, tindakan dan pekerjaan, baik terhadap diri dan pihak lain. Begitu halnya menjadi pendidik tentu harus jujur, baik dari perkataan maupun perbuatan. Karena peserta didik meniru panutannya. Apabila seorang pendidik berbohong maka tidak akan jauh beda dengan peserta didiknya. Buya Hamka menggambarkan 
bahwasanya bersikap jujur adalah salah satu sifat yang harus dimiliki manusia terutama seorang guru, dilihat dari kutipan berikut:

"Perangainya halus, hatinya suci, sikapnya jujur, perkataannya teratur, dan budinya mulia. Kelakuannya baik, mukanya jernih karena ia memandang hidup dengan penuh pengharapan dan tidak putus asa. Apa yang diyakininya, itulah yang dikatakannya dan apa yang dikatakannya, itulah yang diyakininya. Karena itu, kita mengambil kesimpulan bahwa dia seorang "budiman" (Hamka,2014:1).

1. Semangat

Guru harus mempunyai semangat dalam mengajar dan mendidik karena guru memiliki berkewajiban membangkitkan semangat pada peserta didiknya. Buya Hamka menjelaskan bahwasanya :

"Alangkah hebat dan bernas hasilnya jika orang bersemangat dan memiliki cukup ilmu tentang apa yang dikerjakan. Meskipun angan-angan setinggi langit, rancangan sepanjang tali beruk, dilukiskan di atas kertas luas dengan bagan, berjurai berbelit-belit, apalah artinya jika semangat tidak ada "Pasarannya dingin" (Hamka,2014:150).

Hamka menjelaskan bahwasanya menjadi guru juga harus mempunyai semangat dalam mengajar agar dapat membangkitkan semangat peserta didiknya pula.

3. Relevansi Pemikiran Hamka tentang Kepribadian Guru Pendidikan Agama Islam dengan Pendidikan Saat Ini

Dalam dunia pendidikan kepribadian guru akan mewarnai iklim emosional kelas. Kepribadian guru sesungguhnya akan termanifestasikan dalam bentuk aktifitasnya dalam mengajar (Barnawi dan Muhammad Arifin,2012:168).
Artinya, guru yang memiliki kepribadian yang baik akan menciptakan iklim yang kondusif dan memberikan aura positif pada perkembangan psikis peserta didik. Peserta didik akan merasa nyaman, aman, dan senang dalam belajar di dalam kelas maupun di luar bersama gurunya.

Relevansi kepribadian dengan Pendidikan agama Islam, diuraikan terlebih dahulu pengertian pendidikan sesuai Pasal 1 Ayat 1 Undang-Undang Nomor 20 Tahun 2003 tentang Sistem Pendidikan Nasional. "Pendidikan adalah usaha sadar dan terencana untuk mewujudkan suasana belajar dan proses pembelajaran agar peserta didik secara aktif mengembangkan potensi dirinya untuk memiliki kekuatan spiritual keagamaan, pengendalian diri, kepribadian, kecerdasan, akhlak mulia, serta keterampilan yang diperlukan dirinya, masyarakat, bangsa dan negara." (UndangUndang Nomor 20 Tahun 2003, Sistem Pendidikan Nasional, Pasal 1 Ayat (1)).

Hamka berpendapat bahwa guru adalah sosok yang bertanggung jawab dalam mempersiapkan dan mengantarkan peserta didik untuk memiliki ilmu pengetahuan yang luas, berakhlak mulia, dan bermanfaat bagi kehidupan masyarakat secara luas (Hamka,1983:2-3). Namun, seiring berjalannya waktu makna pendidik mengalami pergeseran ke arah yang lebih dangkal. Pendidik dianggap sekedar sebagai orang yang mengajar kepada siswa untuk menambah pengetahuan. Hal ini bertentangan dengan kewajiban pendidik untuk tidak hanya mengajar tetapi sekaligus mendidik. Untuk mencapai tujuan pendidikan secara komprehensif, selain moralitas yang perlu dikuatkan, penguasaan kompetensi materi penting ditingkatkan. Pembekalan ilmu agama dan ilmu umum harus sama-sama dikuasai penuh. Pendidik dalam hal ini mengemban tanggung jawab sebagai pendidik sekaligus pembimbing 
untuk mencapai tujuan pendidikan dari segi jasmani dan rohani, dunia dan akhirat. Hamka menandaskan hal itu dalam pendidikan Indonesia sedianya agar bangsa Indonesia mampu aktif dan bersaing di kancah global.

Menurut Hamka seorang guru hendaknya 'berbuat' sebagaimana layaknya sikap dan tingkah laku anak yang sedang dihadapinya. Dengan pendekatan tersebut, anak akan merasa dekat dengan orang yang mendidiknya. Proses ini merupakan pendekatan yang strategis dalam upaya mencapai tujuan pendidikan yang diinginkan. Dalam hal ini, ia mengutip pendekatan yang dilakukan Rasulullah terhadap Hasan dan Husein. Dalam melaksanakan misi pendidikannya, Rasulullah bahkan tidak segan-segan bermain kuda-kudaan dengan cucu-cucunya. Oleh karena itu, seorang pendidik hendaknya mampu memformulasi bentuk pendekatan pendidikan yang bersifat persuasif terhadap peserta didik, sesuai dengan tingkat perkembangan intelektual dan emosional.

Kepribadian guru terkait seluruh aspek dari pribadi guru yang akan mempengaruhi bagaimana guru menjalankan peran dan tugasnya dalam proses pendidikan dan pembelajaran. Dalam penelitian Murray (1972) mengemukakan bahwa kepribadian guru merupakan variabel yang signifikan dalam proses pendidikan dan pembelajaran. Kepribadian guru merupakan dasar guru dalam berperilaku dalam berbagai bentuk interaksinya dengan peserta didik, pemilihan metode serta pengalaman mengajar yang dipilih. Menjadi guru menuntut suatu personalitas/kepribadian yang terpuji, tangguh dan antisipatif, dengan keterpujian maka dorongan untuk menjadikan masa depan yang lebih beradab menjadi kuat, dengan ketangguhan maka masa depan bangsa yang kuat dalam berjuang menjadi lebih nyata, dan dengan antisipatif maka arah masa depan akan menjadi makin jelas tertata dalam menjalankan peran dan tugas sebagai guru (Uhar Suharsaptra,2013:35).

\section{PENUTUP}

1. Hakikat Guru Pendidikan Agama Islam Menurut Buya Hamka, Guru menurut Hamka berfungsi sebagai lembaga yang berupaya mengembangkan seluruh potensi yang ada dalam diri peserta didik secara maksimal, sesuai dengan irama perkembangannya, baik jasmaniah maupun mental spiritualmemiliki kepribadian yang baik karena peserta didik akan mencontoh ataupun meniru tingkah laku gurunya. Peserta didik maupun masyarakat akan beranggapan bahwasanya guru adalah manusia sempurna yang patut dicontoh.

2. Kepribadian Guru Dalam Pendidikan Agama Islam Menurut Pemikiran Buya Hamka ialah guru harus memahami konsep pendidik sebagai subjek yang dapat diteladani, tugas-tugas pendidik, dan memiliki karakter (sifat-sifat), sebagaimana layaknya seorang pendidik. Hamka mengemukakan pendapatnya mengenai bagaimana harusnya sifat-sifat guru pendidikan agama Islam, yaitu : 1) Memiliki pengetahuan yang luas, 2) Komunikasi yang baik, 3) Tauladan yang baik bagi peserta didik dan yang disekitarnya, 4) Ikhlash, 5) Memiliki metode mengajar yang baik, 6) Rendah hati, 7) Tanggung jawab, 8) Percaya diri, 9) Lemah lembut, 10) Sabar, 11) Semangat, 12) Berlaku dan berkata jujur.

3. Relevansi Pemikiran Hamka tentang Kepribadian Guru Pendidikan Agama Islam dengan Pendidikan Saat Ini guru hendaknya membantu membentuk watak, budi, akhlak, dan kepribadian peserta didik, sehingga ia tahu membedakan mana yang baik dan mana 
yang buruk. Sementara pengajaran Islam adalah upaya untuk mengisi intelektual peserta didik dengan sejumlah ilmu pengetahuan. Dalam mendefinisikan pendidikan dan pengajaran, ia hanya membedakan makna pengajaran dan pendidikan pada pengertian kata. Akan tetapi secara esensial ia tidak membedakannya. Kedua kata tersebut (pendidikan dan pengajaran) merupakan suatu sistem yang saling berkaitan.

\section{DAFTAR PUSTAKA}

Akmal Hawi, Kompetensi Guru Pendidikan Agama Islam, (Jakarta: PT. Raja Grafindo Persada, 2013)

Badiatul Roziqin, 101 Jejak Tokoh Islam Indonesia, (Yogyakarta: e-Nusantara, 2009)

Barnawi dan Muhammad Arifin, Etika dan Profesi Kependidikan, (Jogjakarta: ArRuzz Media, 2012)

Daliar Noer, Administrasi Islam di Indonesia, (Jakarta: Rajawali, 1983)

H.Rusdi Hamka, Pribadi dan Martabat Prof. D. Hamka, (Jakarta: Pustaka Panjimas, 1983) Yunan Yusuf, Corak Pemikiran Kalam Tafsir Al-Azhar, (Jakarta: Pustaka Panjimas, 1990)

Hamka, Akhlaqul Karimah, (Jakarta : Gema Insani, 2017)

Hamka, Ayahku, (Jakarta: Pustaka Panji Mas, 1982), h. 55, lihat juga, Zainuddin Roesmar, Tuntunan Dakwah Dalam Masyarakat Pluralistik Persfektif Metode Dakwah Hamka, (Pekanbaru: Unri-Press, 2002)

Hamka, Falsafah Hidup, (Jakarta:PustakaPanjimas, 1984)

Hamka, Kenang-kenangan Hidup, (Kuala Lumpur: Pustaka Antara, 1982)
Hamka, Lembaga Budi, (Pustaka Panjimas : Jakarta, 1983)

Hamka, Pribadi Hebat ,( Jakarta: Gema Insani, 2014)

Hamka, Tasauf Modern, (Jakarta, Pustaka Panjimas)

Mahmud Yunus, Pokok-pokok Pendidikan dan Pengajaran, (Jakarta: Hida Karya Agung, 1985)

Ngainun Naim. Menjadi Guru Inspiratif Memberdayakan dan Mengubah Jalan Hidup Siswa, (Yokyakarta: Pustaka Pelajar, 2009 )

Nur Hamim, Manusia dan Pendidikan Elaborasi Pendidikan HAMKA, (Sidoarjo: Qisthos, 2009)

Surya Pratama, Kontribusi Buya Hamka Dalam Perkembangan Dakwah Muhammadiyah Tahun 1925-1981, (Skripsi: UIN Sumatra Utara, 2017)

Syaiful Bahri Djamarah, Guru dan Anak Didik Dalam Interaksi Edukatif, (Jakarta: PT Rineka Cipta, 2000)

Syamsul Ma'arif, Guru Profesional: Harapan dan Kenyataan, (Semarang: Need's Press, 2012)

Uhar Suharsaptra, Menjadi Guru Berkarakter, (Bandung: PT. Refika Aditama, 2013)

Zainal Aqib, Profesionalisme Guru Dalam Pembelajaran, (Surabaya: Insan Cendekia, 2002) Suyanto dan Asep Jihad, Menjadi Guru Profesional, (Esensi: Jakarta, 2013) 